
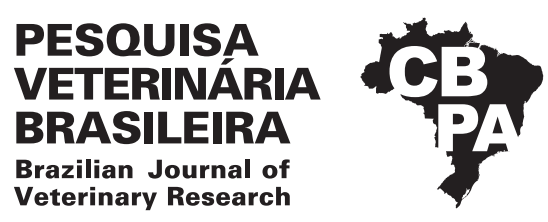

Pesq. Vet. Bras. 39(8):561-563, August 2019 DOI: 10.1590/1678-5150-PVB-5993

ISSN 0100-736X (Print)

ISSN 1678-5150 (Online)

\title{
Seneciosis in cattle associated with ingestion of Senecio brasiliensis under different forms of consumption in Santa Catarina state, Brazil ${ }^{1}$
}

\author{
Claudia P. Biffi ${ }^{2}$, Daiane Ogliari², Elaine Melchioretto², Sandra D. Traverso² (D) \\ and Aldo Gava ${ }^{2 *}$ (i)
}

\begin{abstract}
Biffi C.P., Ogliari D., Melchioretto E., Traverso S.D. \& Gava A. 2019. Seneciosis in cattle associated with ingestion of Senecio brasiliensis under different forms of consumption in Santa Catarina state, Brazil. Pesquisa Veterinária Brasileira 39(8):561563. Laboratório de Patologia Animal, Centro de Ciências Agroveterinárias, Universidade do Estado de Santa Catarina, Av. Luiz de Camões 2090, Bairro Conta Dinheiro, Lages, SC 88520-000, Brazil. E-mail: aldo.gava@udesc.br

This study identified the different forms of ingestion of Senecio brasiliensis in cattle, diagnosed by the Animal Pathology Laboratory at CAV-UDESC, in the state of Santa Catarina, Brazil. A retrospective evaluation from 1987 to 2016 showed that ingestion has occurred voluntarily due to the presence of the adult plant in native field and/or involuntary, due to the presence of the plant in hay and silage, provided in the trough together with other pastures or by contamination in grain residues. These different forms of ingestion demonstrate the importance of epidemiologic investigation in the diagnosis of seneciosis.
\end{abstract}

INDEX TERMS: Seneciosis, cattle, Senecio brasiliensis, consumption, Santa Catarina, Brazil, diagnosis, epidemiology, forms of ingestion, investigation, poisoning by plants, toxicoses.

\begin{abstract}
RESUMO.- [Seneciose em bovinos por ingestão de Senecio brasiliensis sob diferentes formas de consumo, no estado de Santa Catarina.]Esse estudo identificou as diferentes formas de ingestão de Senecio brasiliensis em bovinos, diagnosticados pelo laboratório de Patologia Animal do CAV-UDESC, no estado de Santa Catarina. Através de avaliação retrospectiva referente aos anos de 1987 a 2016, foi possível observar que as formas de ingestão da planta ocorreram de forma voluntária, pela presença da planta adulta em campo nativo, e/ou involuntária, pela presença da planta em fenos, silagens, fornecidas no cocho junto à outras pastagens ou por contaminação em resíduos de grãos. Essas diferentes formas de ingestão demonstram a importância da investigação epidemiológica no diagnóstico da seneciose.
\end{abstract}

TERMOS DE INDEXAÇÃO: Seneciose, bovinos, Senecio brasiliensis, consumo, Santa Catarina, diagnóstico, epidemiologia, formas de ingestão, investigação, intoxicação por plantas, toxicoses.

\footnotetext{
${ }^{1}$ Received on December 19, 2018.

Accepted for publication on February 16, 2019.

Part of the Doctoral Dissertation of the first author.

${ }^{2}$ Laboratório de Patologia Animal, Centro de Ciências Agroveterinárias (CAV), Universidade do Estado de Santa Catarina (UDESC), Av. Luiz de Camões 2090, Bairro Conta Dinheiro, Lages, SC 88520-000, Brazil. *Corresponding author: aldo.gava@udesc.br
}

Original Article Livestock Diseases (cc) EY-NC 


\section{MATERIALS AND METHODS}

The present study retrospectively evaluated epidemiologic and clinical-pathological data of the poisoning outbreaks by Senecio brasiliensis in cattle occurred in the coverage area of the Animal Pathology Laboratory (LAPA) of the "Universidade do Estado de Santa Catarina" (CAV-UDESC) from 1987 to 2016. This study includes the outbreaks diagnosed through clinical evaluation, necropsy, and histologic examination performed by the LAPA team as well as the samples of histologic evaluation sent to the laboratory by veterinarians. Fragments of the organs were collected, fixed in $10 \%$ buffered formalin, routinely processed, and stained with the hematoxylin and eosin (HE).

Data on epidemiology, clinical sign observations, and necropsy findings were collected during the visits to the property where the poisoning outbreaks by $S$. brasiliensis occurred, and they complemented by information obtained from the farm owners and veterinarians.

\section{RESULTS}

From 1987 to 2016, 177 necropsies were performed from 41 outbreaks, of which 17 were diagnosed through necropsy and histologic examination performed by the Animal Pathology Laboratory team and 24 were diagnosed through histologic examination of the samples sent to laboratory by veterinarians. The outbreaks occurred in following municipalities in Santa Catarina state: Lages, Otacílio Costa, Chapecó, Xanxerê, São José do Cedro, Treze Tílias, Água Doce, Campos Novos, Joaçaba, Itaiópolis, Benedito Novo, and Tubarão. The necropsy distribution of the 41 seneciosis outbreaks is illustrated in Figure 1.

The morbidity verified in the 17 outbreaks followed up by the LAPA team varied from 10 to $65 \%$, with lethality of $100 \%$. In the 24 outbreaks with diagnosis performed in the samples received by the LAPA, there was no information regarding the number of cattle affected and the form of ingestion of the plant. The data on the different forms of plant ingestion and the number of deaths in the outbreaks followed up at the LAPA are shown in Table 1. Figure 2 and 3 shows Senecio brasiliensis in alfalfa hay and in harvested pasture.

The clinical signs observed during the visits to the property include diarrhea, apathy, anorexia, progressive emaciation, and rectal tenesmus and prolapse. Aggressiveness, incoordination, walking in circles, and photosensitization were sometimes observed in animals with little pigmentation. In an outbreak in which only calves were affected, the animals also presented constipation.

At necropsy, the most frequently observed clinical signs included liver with reduced size, hardened, yellow or dark, whitish striations, distended gallbladder with thickened wall, and abdominal cavity edema at the abomasum and mesenteric submucose. At microscopy, the main lesions were found in the liver, and were characterized of proliferation of biliary ducts, megalocytosis, fibrous tissue proliferation in various degrees, fatty degeneration, and sometimes, at the nervous system, astrocyte degeneration and moderate spongiosis.

\section{DISCUSSION}

The largest number of cases of poisoning by Senecio brasiliensis diagnosed by the LAPA occurred from 2000 to 2008. Although by that time this plant had already been widely studied and its poisoning effect had been demonstrated (Tokarnia \&
Döbereiner 1984, Barros et al. 1987, Méndez et al. 1987, Driemeier et al. 1991), many producers continued to ignore its effects on cattle.

At that time, the state of Santa Catarina began to gain importance in the national milk production scenario, and today it is the fourth milk producer of the country (IBGE 2017). With the increase in productivity and the need for greater feeding availability, soil management for pasture ended up favoring the occurrence of $S$. brasiliensis. According to Pereira et al. (2011), this plant is mainly observed in native fields where there is no adequate management. In the present

Table 1. Forms of ingestion of Senecio brasiliensis observed in the outbreaks followed up by the Animal Pathology Laboratory, CAV-UDESC, Santa Catarina state, Brazil

\begin{tabular}{lcc}
\hline \multicolumn{1}{c}{ S. brasiliensis ingestion ways } & Outbreaks & Deaths \\
\hline Adult plant in oat and/or ryegrass pasture & 8 & 97 \\
Young plant in native field & 1 & 18 \\
Green plant cut and supplied in the trough & 2 & 9 \\
Contamination of alfalfa and/or oat and/or & 4 & 54 \\
tifton and/or ryegrass hay & & \\
Ryegrass pre-dried silage & 1 & 8 \\
Contamination in grain/corn residues & 1 & 12 \\
TOTAL & 17 & 198
\end{tabular}

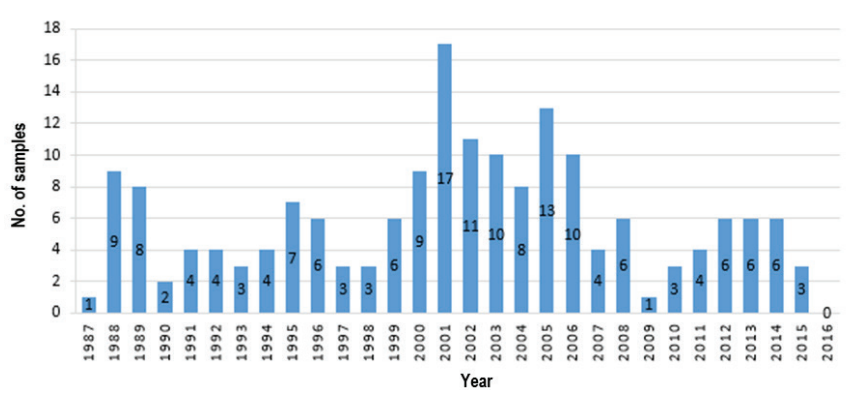

Fig.1. Number of necropsies in cattle affected by seneciosis performed from 1987 to 2016 within the coverage area of the Animal Pathology Laboratory, Santa Catarina state, Brazil.

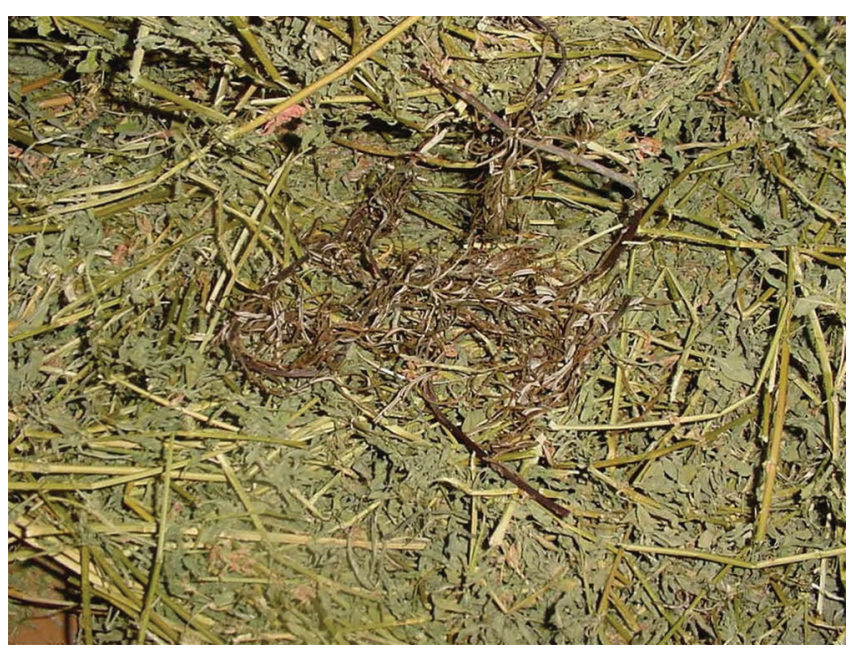

Fig.2. Alfalfa hay contaminated with Senecio brasiliensis leaves. 


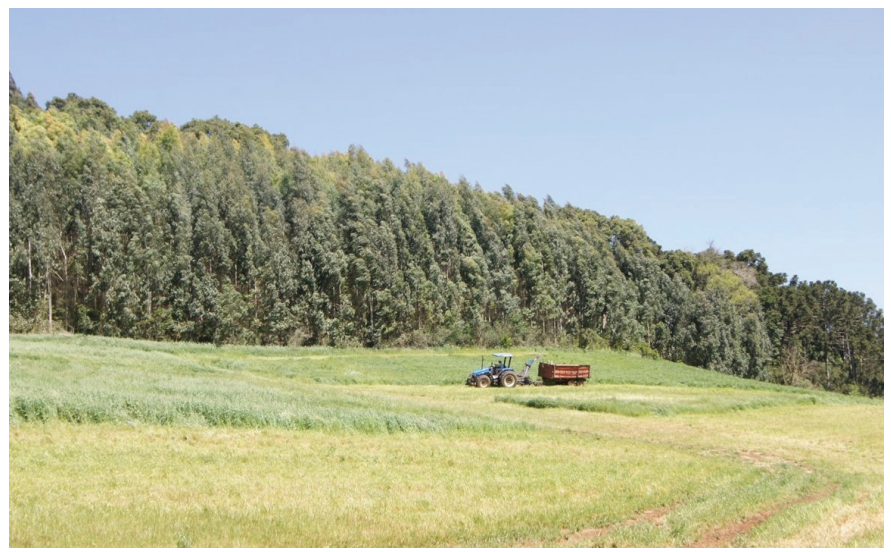

Fig.3. Oat and ryegrass pasture being mechanically harvested for supply to cattle in the trough.

study, of the nine outbreaks resulting from voluntary plant ingestion, only two occurred in native fields, and one of them occurred through ingestion of the young plant. The octhers seven outbreaks occurred through ingestion of the adult plant in areas of oat and ryegrass pasture, differently from the poisoning situation observed by Barros et al. (1987) and Méndez et al. (1987).

In Brazil, there are few reports on the accidental consumption of this plant, (Riet-Correa et al. 1993). Due to the characteristic of being frequently present in the cropped pasture, In Santa Catarina state, because $S$. brasiliensis is frequently present in harvested pasture, it became a contamination source when it is cut together with the pasture and supplied to the cattle in the trough, or, when associated with hay and/or silage, and/or dry grain residues. Even after drying, the plant does not lose its toxicity (Méndez et al. 1987, Méndez et al. 1990, Méndez \& Riet-Correa 2008). Poisoning by S. brasiliensis in cattle in Santa Catarina state, due to management diversity, can occur at any time of the year. This can be explained because, in Santa Catarina state, cattle farming generally occurs in small properties where harvested pasture is frequently used in winter and/or summer when the soil needs to be de-compacted, which favors the spread of $S$. brasiliensis. The seasonal spread of $S$. brasiliensis is also favored when the cattle are fed mechanically harvested pasture supplied in the trough, as well as hay, silage and dry grain residues, which can be used at different times of the year.

S. brasiliensis poisoning diagnosis was confirmed by the pathological clinical condition and observation of the plant consumed in the pasture and/or present in feed such as pre-dried alfalfa, oat and ryegrass, and residues of corn grain.

The seneciosis outbreaks followed up in the present study show that the cattle are exposed to different forms of ingestion of S. brasiliensis. This emphasizes that, in order to obtain the correct diagnosis and take prophylactic measures, accurate epidemiologic evaluation is essential.

\section{CONCLUSION}

Senecio brasiliensis poisoning in cattle in Santa Catarina state was observed due to voluntary ingestion, by hunger, of the adult plant, involuntary ingestion of the young plant in highly contaminated pastures, and/or ingestion of contaminated dry plant residues in hay, silage, grain, and pasture supplied to cattle in the trough.

Conflict of interest.- The authors declare no conflicts of interest.

\section{REFERENCES}

Barros C.S.L., Metzdorf L.L. \& Peixoto P.V. 1987. Intoxicação por Senecio spp. em bovinos. Pesq. Vet. Bras. 7(4):101-107.

Basile J.R., Diniz J.M.F., Okano W., Cirio S.M. \& Leite L.C. 2005. Intoxicação por Senecio spp. (Compositae) em bovinos no sul do Brasil. Acta Scient. Vet. 33(1):63-68. <http://dx.doi.org/10.22456/1679-9216.14565>

Cruz C.E.F., Karam F.C., Dalto A.C., Pavarini S.P., Bandarra P.M. \& Driemeier D. 2010. Fireweed (Senecio madagascariensis) poisoning in cattle. Pesq. Vet. Bras. 30(1):10-12.<http://dx.doi.org/10.1590/S0100-736X2010000100002>

Driemeier D., Barros C.S.L. \& Pilati C. 1991. Seneciose em bovinos. Hora Vet. 10(59):23-30.

IBGE 2017. Instituto Brasileiro de Geografia e Pesquisa. Available at <https:// biblioteca.ibge.gov.br/visualizacao/periodicos/2380/epp_2017_4tri.pdf> Access on Mar. 7, 2018.

Karam F.C., Schild A.L. \& Mello J.R.B. 2011. Intoxicação por Senecio spp. em bovinos no Rio Grande do Sul: condições ambientais favoráveis e medidas de controle. Pesq. Vet. Bras. 31(7):603-609. <http://dx.doi.org/10.1590/ S0100-736X2011000700010>

Karam F.S.C., Soares M.P., Haraguchi M., Riet-Correa F., Méndez M.C. \& Jarenkow J.A. 2004. Aspectos epidemiológicos da seneciose na região sul do Rio Grande do Sul. Pesq. Vet. Bras. 24(4):191-198. <http://dx.doi. org/10.1590/S0100-736X2004000400004>

Méndez M.C. \& Riet-Correa F. 1993. Intoxication by Senecio tweediei in cattle in Southern Brazil. Vet. Human. Toxicol. 35(1):55. <PMid:8434457>

Méndez M.C. \& Riet-Correa F. 2008. Plantas Tóxicas e Micotoxicoses. $2^{\underline{a}}$ ed. Editora e Gráfica Universitária, Pelotas, p.25-32.

Méndez M.C., Riet-Correa F. \& Schild A.L. 1987. Intoxicação por Senecio spp. (Compositae) em bovinos no Rio Grande do Sul. Pesq. Vet. Bras. 7(2):51-56.

Méndez M.C., Riet-Correa F., Schild A.L. \& Martz W. 1990. Intoxicação experimental por cinco espécies de Senecio em bovinos e aves. Pesq. Vet. Bras. 10(3/4):63-69.

Pereira F.A.R., Verzignassi J.R., Arias E.R.A., Carvalho F.T. \& Silva A.P. 2011. Controle de Plantas Daninhas em Pastagens. Embrapa Gado de Corte, Campo Grande, p.1-22.

Riet-Correa F., Méndez M.C. \& Schild A.L. 1993. Intoxicações por Plantas e Micotoxicoses em Animais Domésticos. Editorial Hemisfério Sur, Montevideo. 340p.

Stigger A.L., Estima-Silva P., Fiss L., Coelho A.C.B., Santos B.L., Gardner D.R., Marcolongo-Pereira C. \& Schild A.L. 2014. Senecio madagascariensis Poir. (Asteraceae): uma nova causa de seneciose em bovinos no Sul do Rio Grande do Sul. Pesq. Vet. Bras. 34(9):851-855. <http://dx.doi.org/10.1590/ S0100-736X2014000900008>

Tokarnia C.H. \& Döbereiner J. 1984. Intoxicação experimental por Senecio brasiliensis (Compositae) em bovinos. Pesq. Vet. Bras. 4:39-65. 